\title{
Health and the war. Changing schemes and health conditions during the Spanish civil war
}

\author{
Josep L. Barona $\left({ }^{*}\right)$ and Enrique Perdiguero-Gil $(* *)$ \\ $\left(^{*}\right)$ Departament d’Història de la Ciència i Documentació, Universitat de València. \\ Jose.Luis.Barona@uv.es \\ ${ }^{* *}$ ) División de Historia de la Ciencia, Universidad Miguel Hernández. quique@umh.es
}

Dynamis

[0211-9536] 2008; 28: 103-126
Fecha de recepción: 21 de noviembre de 2007

Fecha de aceptación: 13 de febrero de 2008

SUMMARY: 1.-Introduction. 2.-The Popular Front and the politics of health: changes and controversies. 3.-Health organization after the outbreak of the Civil War. 4.- Impact of the war on population's health. 5.-Evacuation of the refugees. 6.-Experts in action: clinical studies on undernourishment. 7.-The situation at the end of the civil war. 8.-Conclusion.

ABSTRACT: This paper focuses on the health reforms during the republican Spain (1931-1939) and the crisis derived from the three-year of civil war. It considers how the war affected the health system and the impairment of health conditions of the population during the late 1930 s, considering the changing conditions caused by the conflict. Some of the specific topics analysed are the changing healthcare system, the adaptation of health organization after the outbreak of the war, the impact of the war on the health of the population and epidemiological changes, the problem of the refugees and the clinical studies by experts, mainly on undernourishment.

PALABRAS CLAVE: Salud, organización sanitaria, Guerra civil española, refugiados.

KEYWORDS: Health, health organization, Spanish civil war, refugees.

\section{Introduction}

The living conditions and health standards of the Spanish population underwent a slow process of transformation during the interwar period. Public health policies closely related to the participation of the Spanish administration in the international health movement involved the central state and peripheral administration in the building of a public health and 
sanitary system ${ }^{1}$. Programs supported by the Rockefeller Foundation and the active participation in League of Nations Health Organization played a meaningful role ${ }^{2}$. Public Health Services launched several health campaigns and sought new forms of medical care, both in urban and rural districts ${ }^{3}$. Health reforms and attempts to establish a national health service reached a peak during the Republican period ${ }^{4}$.

This process was shown in official reports to the international health organisations. Francisco Murillo acknowledged the difficult epidemiological situation in his report to the Office Internationale d'Hygiène Publique in 1910 and explained the anti-tuberculosis campaigns and the child care and public health programmes (vaccinations, hygiene...) being promoted

1. Among the wide historiography, see the last synthesis by Barona, Josep Lluís; Bernabeu-Mestre, Josep. La Salud y el Estado. La administración española y el movimiento sanitario internacional. Valencia: PUV; 2008

2. Rodríguez Ocaña, Esteban; Bernabeu-Mestre, Josep; Barona, Josep Lluís. La Fundación Rockefeller y España, 1914-1936. Un acuerdo para la modernización científica y sanitaria. In: García Hourcade, Juan Luis; Moreno, J.M.; Ruiz, G., eds. Estudios de historia de las técnicas, la arqueología industrial y las ciencias. Vol. 2, Salamanca: Junta de Castilla y León; 1998, p. 531-539. Dubin, M. The League of Nations Health Organization. In: Weindling, Paul, ed. International health organisations and movements, 1918-1939. Cambridge: Cambridge University Press; 1995, p. 56-80.

3. Barona, Josep Lluís; Bernabeu-Mestre, Josep; Perdiguero, Enrique. Health problems and public policies in rural Spain (1854-1936). In: Barona, Josep Lluís; Cherry, Steven, eds. Health and Medicine in Rural Europe (1850-1945). Valencia: Universitat de Valencia; 2005, p. 63-82.

4. A wide amount of recent research has focused on that period; among the last publications: Barona Josep Lluís. Las reformas sanitarias durante la Segunda República. Eidon. Revista de la Fundación de Ciencias de la Salud. 2006; 22: 22-29; Barona, Josep Lluís; Bernabeu-Mestre, Josep. Apogeo de la ciudad en crisis. Ciencia y sanidad en la Valencia capital de la República (noviembre 1936-octubre 1937). Medicina \& Historia. 2007; 3 (4a época); Barona, Josep Lluís; Bernabeu-Mestre, Josep. Ciencia y sanidad en la Valencia capital de la República. Valencia: PUV; 2007; Bernabeu-Mestre, Josep. La utopía reformadora de la Segunda República: la labor de Marcelino Pascua al frente de la Dirección General de Sanidad, 1931-1933. Revista Española de Salud Pública. 2000; 74: 1-13; Bernabeu-Mestre, Josep. La salut pública que no va poder ser. José Estellés Salarich (1896-1990): una aportació valenciana a la sanitat espanyola contemporània. València: Consell Valencià de Cultura; 2007; Jiménez Lucena, Isabel. El Estado como aliado. Los médicos y el proceso de estatalización de los servicios sanitarios en la Segunda República española. Asclepio. 1997; 49 (1): 193-216; Jiménez Lucena, Isabel. La intervención del Estado en los servicios sanitarios: las expectativas de las fuerzas sociales durante la Segunda República. In: Castellanos Guerrero, Jesús et al., eds. La medicina en el siglo XX. Estudios históricos sobre medicina, sociedad y estado. Málaga: Sociedad Española de Historia de la Medicina; 1998, p. 255-267. 
by the Instituto Nacional de Higiene Alfonso XIII [Alfonso XIII National Institute of Health, hereafter NIH] ${ }^{5}$.

In 1924, the Health Committee of the League of Nations started to publish an International Health Year-Book, which included summarised reports with epidemiological data from the health organisation in each country ${ }^{6}$. The Year-Book contained annual reports on the state of health and sanitary programs, drawn up by the state health officers: Antonio Ortiz de Landázuri, head of the Central Health Brigade; Emilio Luengo, director of the parasitological section of the NIH; Julio Orensanz, Inspector General of Health; and Marcelino Pascua, in charge of the General Directorate of Public Health during the first period of the Republic. Reports on Spain show that the Spanish authorities were aware of the health problems and knew about measures and reforms being implemented in other European countries.

Another interesting source to assess the Spanish health situation of the time is the information arising from the agreement in 1922 between the Rockefeller Foundation and the Spanish government, which has been analysed in detail in other publications ${ }^{7}$.

Elsewhere, in October 1928, Dr. Hapke, medical counsellor of Freiburg (Elba) published a report on the Spanish health service under the title Is our hygiene legislation appropriate for the age or can we learn from other nations? Experiences of a journey of investigation in Spain ${ }^{8}$. The author spent two months travelling in Spain in 1927 in order to report the or-

5. Murillo, Francisco. La réorganisation sanitaire en Espagne. Office International d'Hygiène Publique. Bulletin Mensuel, 1910, 2 (7): 1211-1238. Barona, Josep Lluís. Coping with infectious diseases in Spain. National institutions and fields of action. In: Infektionskrankheiten und Institutionen. Das Robert Koch-Institut in internationaler Perspektive, 1930-1950. Berlin: Institut für Geschichte der Medizin; 2008 (In press).

6. Health Organisation. International Health Year-Book. Geneva: League of Nations; 1925-1932. This source is analysed in Borowy, Iris; Grüner, W.D., eds. Facing illness in troubled times. Health in Europe in the interwar years 1918-1939. Frankfurt a. M.: Peter Lang; 2005. The Spanish reports are discussed in Barona and Bernabeu, n. 1, chapter VIII.

7. Barona, Josep Lluís. Salud, enfermedad y muerte. La sociedad valenciana entre 1833 y 1939. Valencia: Fundació Alfons el Magnànim; 2002, p. 209-309; Rodríguez Ocaña, E. El Informe sobre la sanidad española (1926) de Charles A. Bailey, enviado de la Fundación Rockefeller. Cronos. Cuadernos Valencianos de Historia de la Medicina y de la Ciencia. 2001; 4 (1-2): 6379.

8. Dr. Hapke. Ist unsere hygienische Gesetzgebung zeitgemäss oder können wir von anderen Staaten lernen? Erfahrungen aus einer Studienreise nach Spanien. Zeitschrift für Medicinalbeamte. 1928, 19: p. 37, Spanish version: El Reglamento de Sanidad Municipal juzgado por 
ganisation of the Spanish health services and, influenced by his political ideology favourable to the authoritarian policies of Primo de Rivera, gave a positive view of the situation. The report was published in the German medical press and, as it offered a highly favourable view of the technical and human resources and infrastructure provisions, it was also circulated by the Spanish health authorities.

The development of health services in Spain during the first decades of the 20th century has been widely covered by the historiography. A considerable amount of research on health policies during the Second Republic has added to previous knowledge, showing the importance of the reformist biennium (1931-1933), the debates around the implementation of a state health care service, the professional responses and the health policies ${ }^{9}$.

This paper is focused mainly on the health reforms and the crisis produced by the three-year War, which negatively affected normal conditions and most of the previous gains. It considers how the war and its consequences affected the health system and the health conditions of the Spanish population during the late 1930's, taking into account the changing conditions caused by the conflict.

\section{The Popular Front and the politics of health: changes and contro- versies}

The reports and other sources we are going to analyse made only passing reference to the fact that months after the outbreak of the conflict, on 4th November 1936, the government of the Popular Front set up a new Ministry of Health and Social Care ${ }^{10}$. There was no precedent for a single Ministry for Health, which was allocated powers previously belonging mainly to the

un técnico extranjero. Madrid: Ministerio de la Gobernación, Dirección General de Sanidad; 1929.

9. Some of the latest contributions: Barona and Bernabeu, n. 1; Barona Vilar, Carmen. Las políticas de la salud. La sanidad valenciana entre 1855 y 1936. Valencia: PUV; 2006; Barona, n. 4; Barona, Bernabeu-Mestre, Perdiguero, n. 3; Bernabeu-Mestre, Josep. El papel de la Escuela Nacional de Sanidad en el desarrollo de la salud pública en España, 1924-1934. Revista de Sanidad e Higiene Pública. 1994; 68: 65-89; Bernabeu-Mestre, 2000, n. 4; Bernabeu-Mestre, 2007, n. 4 and Jiménez Lucena, n. 4.

10. The Popular Front won the elections in 1936. It consisted of an alliance of left wing parties, with the support of the socialists, communist and anarchist revolutionary union movement. 
Ministries of Labour and Home Affairs ${ }^{11}$. The anarchist Federica Montseny (1905-1993) was put in charge. She had entered the government with three other members of the anarchist fold as a consequence of the difficult balance between the parties and trade unions supporting the government of the Popular Front that had won the elections in 1936. The creation of the new ministry coincided with the transfer of the government to Valencia in November 1936, as a result of the siege of Madrid. The appointment of Federica Montseny - a female anarchist, professionally uninvolved in medicine and health - was not free of controversy. To begin with, she sought to create a new administrative structure for the Ministry in order to provide union representation. She did away with higher posts in an attempt to foster unconditional collaboration between civil servants and public health experts ${ }^{12}$.

The anarchists had traditionally resisted what they called bourgeois medicine. At the First National Health Congress (Valencia, 1937) of the CNT-AIT, the anarchist Union, a proposal was made to suppress professional medical colleges ${ }^{13}$.The anarchists argued for the unity of a health profession without hierarchy and were highly critical of the government health care model defended by the Socialists and based on the National Institute for Social Care ${ }^{14}$.

In line with this ideology, the anarchist Organización Sanitaria Confederal was set up in 1935, later named Organización Sanitaria Obrera. On the outbreak of the civil war, the anarchist movement unleashed its revolutionary zeal. Its aim was the decentralisation and self-government of the health services by means of a health network at local level with municipal and district plans, and a model of union action, which would have effective control over Ministry guidelines.

11. During the so called Conservative Biennium (1934-1935) health politics were under ministries of Work, Health and Prevision, and Work, Justice and Health.

12. Montseny, Federica Mi experiencia en el Ministerio de Sanidad y Asistencia Social. Conferencia del 6 de Junio 1937 en el Teatro Apolo de Valencia. Valencia: Ediciones de Propaganda y Prensa de la C.N.T.; 1937, p. 9. The minister reviewed her work some years later in: Montseny, Federica. La sanidad y la asistencia social durante la Guerra Civil. In: Los médicos y la medicina en la Guerra Civil española. Madrid: Beecham; 1986, p. 95-101

13. Bases elementales para la organización de la nueva sanidad. Memorias del primer Congreso Nacional de Sanidad de CNT-AIT celebrado en Valencia del 20 al 24 de marzo. Valencia: Editorial Guerra colectivizada; 1937.

14. Barona; Bernabeu Mestre, n. 1. 
In 1937, the Ministry of Health encouraged the creation of a National Health Council and a Social Care Council, made up of a general secretariat, two representatives each from the socialist UGT and the anarchist CNT, and a team of technicians. The creation of the Ministry of Health and Social Care took place in the midst of the war; therefore more ambitious political projects were subjugated to the urgent task of «caring for the health of Spain, and ensuring that war did not lead to epidemics or cause them to spread» ${ }^{15}$ However the military campaign drained public funds and the financial resources of the Ministry were tiny.

Mercedes Maestre, a physician and UGT member, was appointed ministerial sub-secretary, while another female physician, Amparo Poch, took charge of social care and Dr. J. Morata Cantó was made Director General of Health, on the recommendation of the National Health Union. The decree published by the Cabinet on 21st November 1936 incorporated the previous councils and technical boards at the Ministry of the Interior into new National Councils ${ }^{16}$. The Health Council had five sections: Hygiene and Prophylaxis, entrusted with preventing epidemics and infections - particularly critical in times of war; Hospitals and Clinics; Pharmacy and Supplies; Personnel and Professional Organisations; and the General Secretariat.

The new Ministry was confronted by severe challenges: the reorganisation of previous structures of health management in a difficult political and military context, the demarcation of its field of action and the need to make the general conception of public health compatible with the exceptional circumstances of war. Moreover, this had to be achieved with minimal resources. This was a recipe for controversy on several fronts, involving public health experts and political leaders of the Ministry.

The most open and virulent criticism of the health policy of Montseny came from José Estellés Salarich, a socialist and Secretary-General of the Federation of Medical Unions of the UGT, who was appointed SecretaryGeneral of Health in 1936 and then Inspector-General of Health in January 1937 , the technical post with greatest political responsibility within the health structure ${ }^{17}$. Without underestimating the importance of the political tension between socialists, communists and anarchists, which undoubtedly

15. Montseny, n.17, p. 11.

16. Montseny, n.17, p. 97.

17. The critical report of Estellés, under the title Crítica y orientaciones sanitarias [Health cristicism and guidances] is an eight page typed document written in 1937 kept at the Pablo Iglesias 
provided the back-drop to this situation, the disagreements and criticisms reached such a high level that Estellés was reprimanded.

The core of Estellés' attack was centred on his opposition to a transformation of the health organisation based on the state of war ${ }^{18}$. He defended the health of the civilian population in 1937 as an achievement to be protected and questioned some of the minister's political decisions, such as the suspension of the activities of the Central Hospital Board, which depended on the General Directorate of Public Health and the Health Coordination Committee of the Ministry of War. At the same time he criticised the creation of hospitals for convalescents, which he considered to be a waste of resources. Moreover, Estellés disapproved of the indiscriminate setting up of hospitals by unions, political parties or other groups and the creation of health care services in each battalion. He urged the authorities to draw up technical criteria and reorganise services that he held to be numerically adequate.

His report represented a general refutation of the organisational model of the Ministry of Health, proposing an alternative model that involved the gradual implementation of health care collectivisation and an analysis of the main health problems. This would lead to the prioritisation of efforts related to avoidable illnesses that, although under control, were still a risk under war conditions. The plan also included provisions for the prevention of epidemics, a campaign against venereal diseases, measures against infant mortality, the guarantee of food supplies for the civilian and military population, the encouragement of physical and hygiene education and the extension of healthcare services and sanitation in rural areas.

During the rest of the war, civil health underwent hardly any change, while the military health services were reorganised from Madrid by the medical inspector Juan Planelles, one of the leading public health experts and a medical officer. His work included hospitales de sangre [front-line hospitals], hospitales de carabineros [hospitals for military police], and healthcare facilities for separate army divisions, such as the brigada de acero [Steel Brigade] and the Durruti column. Estellés believed that the hospital network was adequate: there were 16,000 beds for the army and a small field hospital.

Foundation Archives: Federación de Sindicatos Médicos de España (correspondencia). Fundación Pablo Iglesias/AH-40-30, hojas 2-87.

18. Bernabeu-Mestre, 2007, n. 4. 
One of the first decrees published by the Ministry of Health was for the creation of a National Supply Committee, designed to centralise the supply of medicines, first aid materials, therapeutic instruments, vaccinations and all of the health provisions needed to deal with civilian and military demands. In spite of its limited operational capacity, the Pharmacy and Supply Section of the Committee, led by a member of the UGT union, managed to set up a large warehouse with all types of medicine.

The National Council of Social Care was established on 14th January 1937, made up of five sections for physically and mental handicapped, mothers and infants, childhood, the struggle against prostitution, and a general secretariat ${ }^{19}$. This initiative reflected an ideology of social protection that was unprecedented in the history of Spain.

The Minister responded to the eugenics proposed by fascism with the defence of a protectionist society inspired by Christian values and a programme of political action, despite the shortage of resources ${ }^{20}$. She put into practice a project to support the social reintegration of prostitutes and set up the Central Office for the Evacuation and Care of Refugees, with headquarters in Valencia and Barcelona ${ }^{21}$. Montseny also prepared a decree to regulate abortion, similar to that which had been in force in Catalonia in August 1936, which was stalled by the opposition of part of the government. The anarchist ministers left the government in August 1938 and most of the projects of this new ministry also disappeared, further victims of the war.

With the incorporation of anarchists into the Government of the Generalitat de Catalunya, Félix Martí Ibáñez (1911-1972) was put in charge of the General Health Office, a post he held for a little over ten months, in which he sought to introduce policies that had been implemented in Republican Spain. The general philosophy of the reforms undertaken by Martí Ibáñez was the transformation of health care by socialising its professional aspects and seeking to change merely curative health services into

19. Estellés Salarich, J. La sanidad del ejército republicano del centro. In: Los médicos y la medicina en la Guerra Civil española. Madrid: Beecham; 1986, p. 37-60.

20. These Christian values were mentioned by Federica Montseny, the anarchist minister of health. See Montseny, n. 17, p. 97-98.

21. Barona and Bernabeu-Mestre, n. 1. 
social and preventive medicine. With regard to social care, he attempted to suppress all elements of private charity ${ }^{22}$.

\section{Health organization after the outbreak of the Civil War}

From the outbreak of the conflict, the future was viewed with concern by international organisations. As mentioned above, the League of Nations, after a proposal by the Spanish government, adopted a resolution on 12th December 1936 to send a team of experts to analyze the situation. The team was headed by Inspector-General A. Lasnet, member of the French Academy of Medicine and former member of the Hygiene Committee of the League of Nations. He was joined by Dr. Laigret of the Pasteur Institute in Tunis and Dr. C. Wroczynski, former General Director of Public Health, Sub-Secretary of State and Chief Medical Advisor to the Ministry of National Education in Warsaw ${ }^{23}$. The commission drew up a Report on three fundamental issues: health organisation, the epidemiological situation and problems arising from the evacuation of refugees ${ }^{24}$. We shall discuss the first issue here.

The first impression of the technical commission was that provincial health infrastructures were well established across the country. Every provincial capital had a general hospital, a hygiene institute and bacteriological and chemical laboratories. This main structure was supported by surgeries, a statistics service, and centres for the elderly, insane and abandoned children. The report also mentioned 'national hospitals', such as the Hospital de la Princesa [Princess Hospital] for infectious diseases in Madrid, the Fontilles leprosy sanatorium, the NHI and the Instituto de Terapéutica Aplicada [Applied Therapeutics Institute]. Before the War, the

22. Martí, José Vicente; Rey, Antonio, ed. Actas del I Simposium Internacional Félix Martí lbáñez: Medicina, Historia e Ideología. Valencia: Generalitat Valenciana; 2004.

23. Barona, Josep Lluís. La salud de la población según los informes internacionales. Congreso Internacional sobre la Guerra Civil Española. Madrid: SECC; 2006; available at http://www. secc.es/ponencias.cfm.: Rapport sur la mission sanitaire en Espagne (28 décembre 1936-15 janvier 1937). Genève: Societé des Nations; 1937, p. 62-63.

24. Anguera, A. Servicios sanitarios con motivo de la inmigración durante la guerra. Revista de Sanidad e Higiene Pública. 1938/39, 25-42; García Luquero. Aspectos sanitarios de la evacuación de refugiados en Santander. Revista de Sanidad e Higiene Pública. 1938/39, 68-81. On refugees see also Clavijo Ledesma, J. La política sobre la población refugiada durante la Guerra Civil 1936-1939. Ph.D. Dissertation, Girona: Universitat de Girona; 2002. 
Spanish health system had 20,000 physicians, supported by public health officers, male nurses performing ancillary medical tasks, female hospital nurses and visiting nurses ${ }^{25}$.

With the outbreak of the Civil War, the Spanish Republic lost an important proportion of health resources. At any rate, the report verified that the Republican zone preserved the provincial and municipal health organization and had sufficient staff and resources to face the situation ${ }^{26}$. However, the Republic had lost virtually all of its Military Health Service, which had to be rebuilt, mainly with civilian doctors. At the end of 1936, the Military Health Corp had 600 physicians, but health supplies were very scarce and prolongation of the war would cause a dramatic shortage. One of the main problems was the means of evacuation for the injured. The health service at the front had only 60 ambulances and some vans and open-top vehicles, wholly inadequate to satisfy needs.

Behind the lines, 70 hospitals were allocated to the war wounded: the hospitales de sangre, 20 of which depended on the Ministry of War and the remainder on provincial authorities, workers' committees and the Red Cross. At the outset, attempts were made to convert convents and other appropriated buildings for the wounded and sick, but the initiative proved chaotic and the number of such installations was small. A total of 25,000 beds were available, including 6,000 in Madrid. One hospital in the capital was set up to treat gangrene and had around 250 patients by the end of 1936, achieving a high (75\%) recovery rate. In the midst of a city under siege and constant aerial bombardment, this hospital managed not only to offer medical care but also to develop scientific innovations ${ }^{27}$.

To assess the situation on the Francoist side, we have the report presented at the League of Nations in 1939 by José Alberto Palanca, Head of the General Directorate of Public Health during and after the war ${ }^{28}$. At the beginning of the war, every province under the Francoist rebels was ruled with wide autonomy by their respective provincial health inspectors.

\footnotetext{
25. Rapport, n. 23, p. 63.

26. A general approach in Bernabeu, Josep. La sanitat a la Guerra Civil espanyola. Un balanç crític. In: Congreso Internacional Valencia, Capital Cultural de la República, 1936-1937. Valencia: PUV; 2008 [Proceedings in press].

27. Barona, Josep Lluís. Josep Trueta i Raspall. La biografía científica de su exilio en Oxford. Laberintos. Anuario de estudios sobre los exilios culturales españoles. 2004; 3: 5-29.

28. Palanca y Martínez Fortún, José Alberto. Les services sanitaires espagnols pendant la guerre civile. Genève: Societé de Nations; 1939, p. 53-70.
} 
However, on $5^{\text {th }}$ October 1936, a Central Health Organization was set up in Valladolid to take the lead on health matters. The National Trust against Tuberculosis was set up on $20^{\text {th }}$ December of the same year ${ }^{29}$.

In January 1937, the provincial inspectors of health and directors of provincial health institutes on the Francoist side met in Valladolid to coordinate health interventions, especially for the healthcare of the Army. They discussed the production and distribution of serum and vaccines, agreed to intensify the struggle against venereal diseases and assessed the problem of malaria and parasitism in the Army and among refugees.

From 1937 onwards, the production of vaccines against typhus, smallpox, rabies diphtheria and tuberculosis in the Francoist zone were distributed among the provincial institutes of health, which sent them to a Health Advisory Centre for delivery according to needs. Greater difficulty surrounded the production of serum ${ }^{30}$. The provincial institute of Badajoz was entrusted with the production of sera against diphtheria and tetanus. In the struggle against venereal diseases, the authorities imposed medical surveillance of prostitutes and increased the production of bismuth and arsenic drugs. The fight against malaria was renewed, with diagnostic screening campaigns and the supply of quinine under the co-ordination of provincial health officers. German aid was decisive ${ }^{31}$. Palanca admitted failure in his efforts to obtain the support of the Rockefeller Foundation to build laboratories. The urgent problem of healthcare in the cities and in rural settings was solved with the help of medical doctors who - according to Palanca's testimony - had escaped from the Republican zone. On 1st February 1938, the Francoist government launched the National Health Service, with its headquarters in Burgos. Some management staff from the Republican central administration joined the new service, including Julio

29. Bulletin de l'Officine Internationale d'Hygiène Publique. 1940; 32 (1): 20. Molero-Mesa, Jorge. Health and public policy in Spain during the early francoist regime (1936-1951): the tuberculosis problem. In: Löwy, Iliana; Krigge, John, eds. Images of disease. Science, public policy and health in post-war Europe. Luxembourg: Office for Official Publications of the European Communities; 2001, p. 141-165.

30. Palanca y Martínez Fortún, n. 28.

31. The real content of German aid in the field of health and medicine and its effect on the development of the war has not been studied and is one of the gaps in the historiography. Several testimonies of the time refer to it and Palanca himself refers to German aid with laboratory products. 
Orensanz, previously one of the Spanish representatives at the League of Nations Health Organization ${ }^{32}$.

Besides the re-organisation of the health services on both sides of the conflict, a fundamental aspect of healthcare during the war was foreign aid ${ }^{33}$. On 3rd and 4th July 1937, an international conference was held of the Centrale Sanitaire Internationale d'aide à l'Espagne Républicain, and attended by delegates from 11 countries: United Kingdom, Belgium, Canada, United States of America, the Netherlands, Norway, Sweden, Switzerland, and Czechoslovakia. They met a high-level Spanish delegation: Antonio Madinaveitia represented the Health Service of the Minister of War; Juan Planelles participated as Sub-Secretary of State of the Ministry of Public Health, Luis Bilbao as representative of the government of Euskadi, and Oskar Telge as representative of the health services of the International Brigades. The meeting was chaired by the ambassador in Paris, Ángel Ossorio y Gallardo.

The Centrale Sanitaire set up an International Committee, under Dr. Kalmanovitch, in order to coordinate information on requests and to send health supplies ${ }^{34}$. The Centrale Sanitaire organized a regular exchange of information. After the International Conference, the Secretary-General travelled to Spain with medicines, photographs and leaflets for health products. In Valencia, he publicised the countries involved in the international aid effort on the radio and in the press, forging a link that had positive practical effects and a positive psychological impact. The Central Sanitaire published a Bulletin to win over the support and solidarity of doctors and public and collect funds and health materials.

The Centrale Sanitaire collaborated further by sending nurses and doctors to Republican Spain. Kalmanovitch published an article in the Bulletin about the way health services were working at the front. His commentary contained detailed reports on the health organisation and the state of health of the population. He also described the coordinated groups of stretcher bearers and nurses established on the battlefields to offer first aid to the

\footnotetext{
32. Palanca, n. 28, p. 57; Barona y Bernabeu, n. 1.

33. Beneito, A. La cooperació sanitària internacional i I'hospital Suec-Noruec d'Alcoi. In: Congreso, n. 26.

34. The information in the Bulletin d'Information de la Centrale Sanitaire Internationale d'aide à I'Espagne Républicaine indicates that the initial contribution of each country in French francs was: Great Britain, 76,000; U.S.A, 906,000; France, 239,500; Holland, 46,200; Norway, 28,500; Sweden, 315,000; Switzerland, 12,500; total, 1,623,700 francs.
} 
wounded. There were also battalion treatment posts, with doctors, nurses and stretcher bearers and the technical and human resources to treat the most urgent cases. These posts were as close as possible to the front-line, with a road allowing access for ambulances, and they tended to be located in small abandoned farmhouses or huts, although sometimes the only option was to use a tent that was not always well equipped but was protected by sandbags from enemy fire.

There was a brigade post, usually at a distance of around two or three kilometres from the battalion first-aid post, with a brigade physician, several assistant physicians, nurses, stretcher bearers and ambulances. There were three types of ambulance: small ones with bunks for the seriously injured, those with seating arrangements for five patients, and larger ambulances with four bunks and ten or twelve seats. The brigade medical post also served as an ambulance station, with the vehicles hidden among trees. The wounded were superficially assessed at this post, evaluating the degree of urgency after examination of the injuries. Those who could be treated in situ were then returned to the front, while those requiring hospital treatment were moved to a rearguard hospital, where there were beds, operating theatres, treatment rooms and other hospital services. Rearguard hospitals could treat between 700 and 800 patients. The important factors were considered to be the speed of evacuation, the proximity of treatment facilities and the availability of free beds.

Naturally, many other organisations and groups also played their part in healthcare, including the Red Cross, International Red Cross, Red Aid International, among others. There were also specific initiatives, e.g., the Swedish-Norwegian Hospital set up in Alcoy ${ }^{35}$.

\section{Impact of the war on population's health}

During the first year of the war, all available data show a controlled epidemiological situation with no signs of degradation or unexpected epidemic outbreaks. The health of the population in the Republican zone remained within usual limits. The stable population had adequate supplies, but the refugees suffered severe shortages. This apparent normality surprised

35. Beneito, n. 33; Barona; Bernabeu Mestre, n. 1. 
the League of Nations experts visiting Spain at the beginning of $1937^{36}$. However, the situation began to worsen, as shown by general mortality rate trends. During 1930-1935 the rate was 14.5 per thousand, and in 1937 it was only 15.5 but gradually increased during the war to a peak of 19.2 per thousand in 1938. When the Civil War finished, there was a decrease in general mortality during a three-month period, but there was then an increase in 1940 that brought the rate up to 16.6 per thousand. There was a further increase in 1941, due in part to food shortages and to the high infant mortality associated with a spectacular increase in the birth rate in $1940^{37}$.

The system for epidemiological data collection set up by Marcelino Pascua during the first Republican biennium was profoundly altered by the war and the data collection was imperfect. However, it still permitted identification of the four main problems to be addressed, i.e., typhoid fever, spotted fever, smallpox and bacillary dysentery, inevitable consequences of wartime living conditions ${ }^{38}$.

According to the League of Nations report, typhoid fever had been an endemic problem since before the war, due to the poor hygiene conditions of water for human consumption. At the start of the 1920s, cases ranged from 15,000 to 20,000 annually, causing around 3,000 to 4,000 deaths. There was a marked reduction in cases during 1934-1935, but the situation worsened after the outbreak of war due to the deterioration of sanitary conditions and the movement of refugees, according to data used by the expert committee and based on statistics compiled by the National Hospital of Infectious Diseases. There were 358 cases in the second half of 1936, with 42 ending in death. At any rate, the experts expressed their reservations and reported that health services had been reorganised and that bacteriological water testing was being carried out on a regular basis. Because an epidemic was not expected, an intensification of typhoid vaccination was not recommended.

Spotted fever, traditionally associated with situations of war or catastrophe, had not yet shown signs of exacerbation at the start of 1937, when

36. Rapport, n. 23, p. 72; Biraud, Yves M. Health in Europe. A survey of the epidemic and nutritional situation. League of Nations Bulletin of the Health Organisation. 1943/44, 10 (4), p. 532-593.

37. Barona, n. 23.

38. Rapport, n. 23, p. 72-73. 
the experts from the League of Nations wrote their report. It had been a serious problem in Spain in 1919 and 1920, but was brought under control in $1935^{39}$. The commission experts were satisfied with the measures put into place by Spanish authorities, i.e., immediate de-lousing and vaccination if there was potential for an epidemic.

Bacillary dysentery had caused 64 deaths in 1934 and 105 in 1935, and a worsening of the situation was feared at the start of the war. As a consequence, a special coprological examination service was established at the NHI, which continued until November $1937^{40}$. Only eight cases and one death were officially recorded. Although there were many cases in Asturias, precise numbers could not be estimated. The experts did not consider the situation to be epidemic. All surveillance systems were in place in case the situation worsened.

Other health problems were considered to be of lesser importance or not affected by war conditions. No deaths were caused by smallpox, although experts recommended that medical authorities be on the alert for deaths from smallpox in Spanish Morocco and Portugal. The health mission noted a worsening in the morbidity and mortality of malaria, but other infectious diseases had not been affected by the war conditions. A main goal of the hospitales de carabineros was the control of malaria ${ }^{41}$.

The official data on notifiable diseases for the Madrid area from 19 July 1936 to 1 January 1937, compiled by the Hospital Nacional de Enfermedades Infecciosas, are shown in Table 1:

The report also included data compiled in Valencia for all of the Republican zones, but only for three weeks in December. We highlight the 258 cases of typhoid fever, with 42 deaths, and the 1,027 cases of German measles, with only 4 deaths.

The global epidemiological survey detected no epidemics or even sporadic outbreaks. The measures adopted by the Republican government consisted of recruiting all medical professionals of the country, coordinating the actions of the civil and military medical authorities, adopting special measures to ensure the proper functioning of medical aid on the front and developing a vaccination campaign. There was typhoid and paratyphoid

39. It caused 227 and 153 deaths, respectively. There were only three deaths in 1935.

40. Rapport, n. 23, p. 73-74.

41. Calandre, Cristina. El Dr. Luis Calandre Ibáñez. Su actuación en la Guerra Civil Española (19371939). Frente de Madrid. 2007; 11: 6-11. 
Table 1. Diseases of compulsory notification registered in the Madrid area, 19 July 1936 to 1 January 1937

\begin{tabular}{|c|c|c|c|}
\hline & Cases & Deaths & $\%$ Mortality \\
\hline Typhoid Fever & 358 & 42 & 11.7 \\
\hline Paratyphoid Fever & 6 & - & - \\
\hline Pneumonia & 88 & 9 & 10.2 \\
\hline Dysentery & 8 & 1 & 12.5 \\
\hline Puerperal septicaemia & 10 & 6 & 60 \\
\hline Tetanus & 5 & 2 & 40 \\
\hline Pertussis & 83 & 3 & 3.6 \\
\hline Poliomyelitis & 1 & - & - \\
\hline Malaria & 46 & - & - \\
\hline Diphtheria & 3 & - & - \\
\hline Anthrax & 15 & - & - \\
\hline Tuberculous Meningitis & 14 & 14 & 100 \\
\hline Malta Fever & 20 & 2 & 10 \\
\hline Scarlet Fever & 80 & 8 & 10 \\
\hline Erysipelas & 71 & 4 & 5.6 \\
\hline Brain-Spinal Meningitis & 4 & 2 & 50 \\
\hline Rubeola & 99 & 10 & 10 \\
\hline Lung Tuberculosis & 456 & 58 & 12.3 \\
\hline Carbuncle & 8 & - & - \\
\hline Endocarditis & 26 & 8 & 30 \\
\hline Encephalitis & 1 & 1 & 100 \\
\hline Flue & 41 & 2 & 1.8 \\
\hline Chickenpox & 11 & - & - \\
\hline Amygdalitis & 30 & - & - \\
\hline Other cases & 287 & 40 & 15 \\
\hline Total & 1,778 & 212 & 11.9 \\
\hline
\end{tabular}

Source: Rapport sur la mission sanitaire en Espagne (28 décembre 1936-15 janvier 1937). Genève: Société des Nations, 1937, p. 95.

fever vaccination in the army, and relatively widespread paratyphoid fever vaccination of civilians. Smallpox vaccination was compulsory but diphtheria vaccination was rare, never having been widespread among the population. No other preventive vaccination was given to soldiers, not even against tetanus. 
Based on their observations and the official data they had compiled, the League of Nations experts considered the health situation to be satisfactory at the start of 1937, although they feared the spread of typhoid and spotted fevers. They therefore recommended compulsory vaccination, water and food testing. With regard to spotted fever, they laid out recommendations to improve treatment and prevention, including the use of portable de-lousing devices and therapeutic materials, general immunisation against typhus for health workers and a greater availability of vaccines. They thought it necessary to take the following steps: equip municipal and provincial centres with specific areas for the treatment of patients with infectious diseases; provide health services with disinfection equipment, which was clearly inadequate; isolate contagious patients; and improve epidemiological data collection systems for the timely detection of any sign of deterioration in the health situation. A central feature was the training of doctors specialised in epidemics, who could be specifically assigned to prophylaxis and the fight against infections, working in asylums, prisons and other places where large groups of people lived.

A report on the Francoist side presented by J. A. Palanca to the League of Nations in 1939 commented on the main health problems in the rebel Army and the health situation of the civilian population ${ }^{42}$. The report was rather unrealistic, attempting to demonstrate that actions taken before the war allowed a controlled epidemiological situation during the war in the Francoist zone. Palanca, in a triumphant tone, claimed that widespread use of typhoid vaccination alongside strict water testing had prevented any problems. Efforts had to be redoubled when the Northern provinces (Santander, Bilbao, Asturias) were taken, but the situation remained under control. He even said that mortality due to disease probably continued to decrease throughout the war. He also cited the good situation with respect to spotted fever, stating that on the Francoist side there had only been one case, despite the large contingents of refugees coming from the enemy zone. The incessant taking over of new territory required special surveillance of ports, prisons, asylums and concentration camps. A cordon sanitaire had been established, with disinfection equipment and delousing stations in areas in contact with the enemy in order to prevent the disease.

42. Palanca y Martínez Fortún, n. 28. 
With regard to malaria, the report indicated that the anti-malarial programme established before the war was, as far as possible, ongoing ${ }^{43}$ and that the medical dispensaries functioned with regularity and had sufficient medication. However, the potential for a worsening of the situation was recognised. Troop movements and the destruction of cities had created new malarial outbreaks that needed to be addressed, especially in areas with malaria-free anopheles mosquitoes. Although no data were available, it was thought that the number of malaria patients must have been considerable, especially in the armies on both sides ${ }^{44}$.

Palanca briefly mentioned leprosy, pointing out that the policy of patient isolation that had existed before the war remained in force, using institutions in Galicia and Andalusia. Medication was sufficient, and with the end of the war, the leper colony of Fontilles was once again available for isolating patients.

In contrast, venereal diseases were a serious problem, as usual during war, especially among soldiers. Outpatient treatment at dispensaries continued, along with the reservation of some isolation beds in hospitals and the creation of a few isolation centres. In addition, prostitutes who were contagious were isolated. Attempts were made to combat the disease by drug therapy, using arsenic and bismuth.

Palanca acknowledged that diphtheria was one of the more serious problems. By 1935, the mortality rate from this disease had decreased to 5 per 100,000 inhabitants. Although the war did not seem to have increased this rate, there was a rise in the number of cases. Anatoxin had not been available because the heating equipment was being used for the production of the typhoid vaccine, but this situation was resolved by the supply of anatoxin and antidiphtheria sera from some provincial laboratories.

The report showed some concern about smallpox, since the number of cases had increased and various epidemic outbreaks had arisen that were difficult to isolate due to transport-related problems. An intensive vaccination campaign was under way and, despite some technical difficulties, health institutions were producing «millions of doses of the vaccine». At any rate, the mortality was nil because most were cases of varioloid and there had been no complications in the few cases of smallpox.

43. See Rodríguez-Ocaña, Esteban et al. La acción médico-social contra el paludismo en la España metropolitana y colonial del siglo XX. Madrid: CSIC, 2003.

44. Palanca, n. 28, p. 66. 
Although Palanca was also somewhat concerned about other problems such as trichinosis and rabies, aggravated by difficulties in veterinary care, he believed them to be controllable once surveillance and treatment programmes were reinstated. The completion of Palanca's report coincided with the end of the war, when the necessary reconstruction of healthcare to the population was already in progress.

\section{Evacuation of the refugees}

The evacuation of refugees fleeing from the front to neighbouring areas was another fundamental issue affecting the health of the population. The League of Nations report showed that 250,000 refugees from Extremadura lived in Jaén, Ciudad Real and Toledo and that Catalonia had received large numbers of refugees from Aragón. The flow of refugees aroused the spontaneous solidarity of families living in host zones, but it was necessary to set up a National Committee for War Refugees. The provincial and local delegations of this committee were in charge of the evacuation, distribution and housing of refugees ${ }^{45}$. Funding for their care came from private sources and the national budget.

Enormous difficulties were posed by the evacuation of populations from the front. Out of the estimated one million refugees at the end of 1936, hosts were found for 350,000 in Catalonia and 250,000 in Valencia ${ }^{46}$. Refugees accounted for $14 \%$ of the whole population of the country, and the capacity to take on new refugees was on the verge of saturation, with the beginning of food shortages in some areas. The evacuation of Madrid, which was under siege, was very difficult, and the experts predicted a dramatic worsening of the health and nutritional status of the population.

After the first months of the war, the food supply became a problem for the more than one million inhabitants of Madrid and the hundreds of thousands of refugees that had arrived in the capital from the neighbouring province of Toledo and the region of Extremadura. The war front divided the country into two factions. The east was under Republican control and the rebels held the west and the north. The Republican zone produced wheat,

45. Rapport, n. 23, p. 78-91.

46. Rapport, n. 23, p. 86. 
rice, vegetables, fruit and wine. The zone controlled by Franco's troops also produced cereals, but mainly comprised pasture lands. In January 1937, the experts from the League of Nations predicted that the inhabitants of Madrid would suffer shortages of meat and milk but that the supply of flour, olive oil, fruits, pulses and vegetables was guaranteed if the Republican authorities could maintain the transportation system. The worst predictions came true. Although the lack of milk and meat was, at the beginning, alleviated by other products, transport problems meant that there were long queues of people 'in a perfect state of health' at the shop doors ${ }^{47}$.

The League of Nations experts devoted an annex of the report to the nutritional status of the civilian population and their fears were borne out. From the second half of 1937, the population of Spain suffered food shortages, which some experts describe as more severe than those produced in central Europe during the Great War (1914-1918) ${ }^{48}$. In Madrid, the caloric value of the diet decreased from the first winter of the war (1936-1937), leading to a progressive undernourishment of the whole population ${ }^{49}$.

After the war, in mid-1939, the League of Nations Technical Commission on Nutrition reported on the work done between June 1938 and April 1939, including data on the critical nutritional condition of refugees. The experts asked for an urgent solution to be found to avoid deaths by starvation.

\section{The situation at the end of the Civil War}

Once the war had ended, Palanca presented a new report on the health situation in Spain ${ }^{50}$. It appeared to be more pessimistic than the previous report, which had striven to transmit the idea of a controlled and reorganised response to all of the problems that had arisen during the war. He considered that changes between the end of the war and 1939 had worsened the epidemiological situation. Nevertheless, he claimed that a catastrophic

\footnotetext{
47. Rapport, n. 23, p. 96.

48. Grande Covián, Francisco. L'alimentation et les troubles alimentaires pendant la Guerre Civile Espagnole. In: Les Vitamines. Bâle: Roche, 1944.

49. Jiménez García; Francisco; Grande Covián, Francisco. Sobre los trastornos carenciales observados en Madrid durante la Guerra. I. Los cuadros clínicos presentados con más frecuencia y su clasificación. Revista Clínica Española. 1940, 1, 313-318.

50. Palanca y Martínez Fortún, n. 28, p. 40-52
} 
progression of this trend would be avoided thanks to the efforts of health workers of the General Directorate of Public Health.

The changes referred to by Palanca were the reappearance of spotted fever and smallpox cases, with small outbreaks occurring in some provinces. Palanca blamed the propagation of smallpox on the cross-country migrations of large military and civilian populations at the end of the war. He remained optimistic, however, believing that this apparent propagation did not reflect reality, since the infection had come up against a barrier of immunised individuals in most provinces, definitively halting its spread.

Cases of spotted fever, which Palanca claimed had not occurred in Francoist areas before contact with enemy lines, also began to be detected, with a small outbreak in the province of Cuenca. The origin of the epidemic was related to cases in the province of Murcia before its conquest by fascist troops. A similar causal link was also proposed for cases reported in Malaga, Madrid and a small outbreak that had recently occurred in Villarrobledo (Albacete). The origin of the disease was always attributed to the Republican area and the report tried to minimise its importance.

According to Palanca, the deficient health conditions at the end of the war had been worsened by the large population movements, notably in Madrid. The city had been subject to an incomplete siege for two and a half years, and the population had lived under very poor food supply and housing conditions. In addition, during the post-war period, Madrid's privileged central location made it especially prone to population movements by both immigrants and emigrants and to a constant transit of large masses of people through the city. This led to the appearance of spotted fever and smallpox cases in the capital and an unprecedented number of cases of diphtheria, with a notable worsening of endemic typhoid fever.

The smallpox situation had significantly worsened during the final year of the war from practically no reported cases before November 1938 to 288 official cases within ten months, and the true incidence of the disease must have been even higher. The ending of vaccination campaigns explains this worsening, since most cases emerged in population groups that had not been vaccinated or had been vaccinated more than seven years earlier.

New cases of diphtheria began to be detected from August 1938. During September, 254 cases were reported in Madrid, causing 27 deaths and prompting the adoption of emergency measures to produce anti-diphtheria serum and launch anatoxin vaccination campaigns. Nevertheless, at the end of 1939, diphtheria cases were continuing to rise among the child population. 
Finally, typhoid fever also caused deaths among the Spanish population at the end of the civil war, with reports of epidemics in many towns and of re-infections that were very difficult to control. A strategy was developed to isolate patients in hospitals but this was difficult to implement, as was the chemical disinfection of instruments and products that could potentially transmit the disease. Vaccination campaigns were mounted, with the administration of more than 300,000 vaccinations in a few months. However, medical technology could do little to resolve the major health problems caused by the destitution of the population. The ravages of a three-year civil war and the poverty experienced during the post-war period placed Spanish society in a greatly deteriorated social and health situation at the start of the 1940s.

We can turn to yet another source to help us evaluate the health condition of the Spanish population at the end of the war. On 20th August 1939, the Rockefeller Foundation drew up a report on the situation of Spanish society, with data on various aspects of Spanish life. With regard to health, the report recognized the achievements of the Republican health services but pointed out the occurrence of epidemic outbreaks and the appearance of malnutrition in wide sectors of the population ${ }^{51}$.

The report acknowledged that there had been great progress in health organisation before the war, starting with a core group mainly composed of old interns from the Rockefeller Foundation. However, it described a deterioration in this situation from 1939, with the appearance of epidemic diseases immediately after the war. It reported on the increased prevalence of smallpox, spotted fever, malaria and typhoid fever, even though the spread of the latter was not yet considered alarming.

The report also noted the destruction of health resources in Madrid, where many centres located on the firing line had been reduced to rubble. The destruction had also been quite serious in the rest of the country, with severe damage to various provincial Hygiene Institutes, cornerstones of the territorial heath organisation. The Foundation was aware of the need to carry out a major reconstruction task in a very complex situation. In-

51. Report on the health situation in Spain. Rockefeller Foundation, 20 August, 1939. Rockefeller Archive Centre (RAC), New York. See also the «Notes on the food situation in Spain» drawn up on October 1940 by F. H. Janey from the Rockefeller Foundation. See also: Del Cura, Isabel; Huertas, Rafael. Alimentación y enfermedad en tiempo de hambre: España 1937-1947. Madrid: CSIC; 2006, p. 111-118. 
deed, the government was in serious financial difficulties. The cost of war had been enormous, the gold reserves had disappeared, the cost of living in Madrid had doubled, with inflation rising to unprecedented extremes, and the taxation system still lacked a solid foundation. A significant part of Madrid had been destroyed, and an incalculable number of towns and cities had been reduced to rubble. In addition to those who had lost their lives, wide sectors of the population had become immersed in poverty. The report considered that the State was making great strides to help those affected, but it had to face this terrible situation in an international context of isolation and conflict.

Probably the most striking aspect of the report was its positive attitude towards the new health authorities and especially the Director General for Health, J.A. Palanca. It stated that, except in some cases, the medical workers had continued working during the conflict, respected by both fronts as experts, with no reason to interfere in their work. Although a purge of public health workers who had served in the «red» zone was under way, the Rockefeller Foundation predicted a happy ending ${ }^{52}$. Evidently, the information received by the Rockefeller Foundation was manipulated and did not correspond to reality, since the public health experts were severely punished after the war. In fact, the majority of them went into exile and participated actively in foreign and international posts in Venezuela, Mexico, Cuba, the Pan-American Health Office or the WHO over the following decades.

\section{Conclusion}

The participation of the Spanish authorities in international health conferences and international health institutions, such as the International Bureau of Hygiene and the League of Nations Health Organization with the support of the Rockefeller Foundation contributed to build in Spain a health system equivalent to those working in other European countries. After the proclamation of the Second Republic some of the experts trained in public health with the support of the Rockefeller Foundation took over the running of health affairs launching a health reform with a bigger budget

52. A whole chapter in Barona and Bernabeu, n. 1, is devoted to showing the major problem caused by the exile of public health experts. 
and the support of the government. The beginning of the Civil War obstructed the reforms, although the work done prevented the population's health status from being severely damaged during the fist two years of conflict. The 1937 report of a team of experts from the League of Nations that analysed the situation of the republican side, and the 1939 report by José Alberto Palanca, Head of the Francoist General Directorate of Public health, pointed out deficiencies but explained the reorganization of health services with the available resources and a model of healthcare at the front and the rearguard. Germany supported laboratories on the Francoist side and the Centrale Sanitaire Internationale d'Aide a l'Espagne Républicaine gave support to the Republic.

Although the care of the refugees was from the beginning a big problem, health indicators only showed a slight worsening, stronger from autumn 1937. Then, to traditional health problems as infant mortality, tuberculosis, venereal diseases and malaria there were added four great threats: epidemic outbreaks of typhoid, sporadic outbreaks of spotted fever and smallpox, and an increase in the incidence of bacterial dysentery. Diphtheria, almost absent before the war, reappeared strongly among children. From August 1938, supply and transport problems drastically decreased the food intake of the population. Deficiency illnesses as a consequence of the lack of vitamins and proteins in the diet affected wide sectors of the population and allowed health experts to study several of these diseases. The first years after the war seriously worsened the health status of the majority of Spanish society and once again allowed new studies on nutrition with the support of the Rockefeller Foundation. 